\title{
Nuclear targets within the project of solving CHAllenges in Nuclear DAta
}

\author{
Goedele Sibbens ${ }^{\mathrm{a}}$, André Moens, David Vanleeuw, David Lewis, and Yetunde Aregbe \\ European Commission - Joint Research Centre - Directorate for Nuclear Safety and Security, 2440 Geel, Belgium
}

\begin{abstract}
In the frame of the European Commission funded integrated project CHANDA (solving CHAllenges in Nuclear DAta) the importance of nuclear target preparation for the accurateness and reliability of experimental nuclear data is set in a dedicated work package (WP3). The global aim of WP3 is the development of a network for nuclear target preparation and characterization, enabling to coordinate the target production corresponding to the experimental requirements. Therefore, a set of tasks within the work package needs to be followed. Primarily, an inventory of target related facilities and radioisotope providers was created. In the next step a priority list of target requests was made in agreement with the target user considering the technical specification, the scheduled experiments and the availability of the target laboratories.

A set of target requests has been assigned to the Target Preparation laboratory of the European Commission - Joint Research Centre - Directorate G (EC-JRC.G.2) in Geel, Belgium. This contribution gives an overview of the nuclear targets that are produced within the CHANDA project. The equipment and techniques available for the preparation and characterization of uranium, plutonium and neptunium layers with an areal density ranging from 60 to $205 \mu \mathrm{g} \mathrm{cm}^{-2}$ will be emphasized.
\end{abstract}

\section{Introduction}

Experiments with the aim to improve the quality of nuclear data require samples used as "targets". A big challenge among others is firstly to have the base target material of a particular isotope available, secondly to prepare the target and finally to characterize it. The quality and characteristics of the target have an effect on the uncertainty of the measured nuclear data and so determine the success of the experiment. Unfortunately only a few laboratories are able to prepare high quality nuclear targets because of the high costs related to radioprotection and safety, the decrease in human resources, the difficulties to find high-purity material and the required high level of technology and know-how. So in order to have high quality tailor made targets available for the nuclear data measurements within the above mentioned constraint, it is beneficial to share the existing know-how and expensive equipment and to focus on the complementarities of still existing target production facilities. This need has been described in the work package WP3 of the project of solving CHAllenges in Nuclear Data (CHANDA) [1]. Although the CHANDA partners include most of the participants in FP7 nuclear data projects: ANDES [2], EUFRAT [3] and ERINDA [4]; for the first time a work package is dedicated to target preparation. The aim of WP3 is to create a network of laboratories for the preparation and characterization of samples and targets for nuclear data experiments and to improve the communication channels between target users and producers in the EU and world-wide. The WP3 activities include the coordination of efforts and resources as

$\overline{\text { a e-mail: goedele.sibbens@ec.europa.eu }}$ well as the preparation of targets. First an inventory of target related facilities and radioisotope providers was made indicating their capabilities and limitations. Hence a workshop on "target preparation - the needs and the possibilities" was organised by the Paul Scherrer Institute in Villigen, Switzerland [5] to improve the contact between the target producers and users. A common priority list of target requests was made considering the technical specification, the scheduled experiments and the availability of the target laboratories. Consequently, the preparation and characterization of uranium, plutonium and neptunium layers with an areal density ranging from 60 to $205 \mu \mathrm{g} \mathrm{cm}^{-2}$ was assigned to the EC-JRC.G.2 in Geel, Belgium [6].

\section{Actinide target requests within CHANDA}

The target requests for uranium, plutonium and neptunium layers listed in Table 1 were discussed with the spokesperson and target user of the experiments approved in the CHANDA Program Advisory Committee (PAC) meeting. The preparation method, material, backing and dimensions were chosen in function of available actinide material, equipment, know-how, human resources and delivery time.

\section{Experimental details}

\subsection{Material}

Highly pure material of ${ }^{239} \mathrm{Pu},{ }^{237} \mathrm{~Np},{ }^{235} \mathrm{U}$ and ${ }^{238} \mathrm{U}$ oxides were selected from the available stock. The mass fractions, determined by thermal ionization mass spectrometry, are 
Table 1. Target requests for approved CHANDA experiments.

\begin{tabular}{|c|c|c|}
\hline PAC & Experiment & Targets \\
\hline $1 / 2$ & $\begin{array}{c}\text { First ever correlation } \\
\text { measurements of prompt fission } \\
\gamma \text {-rays and fission fragments from } \\
\text { the reaction }{ }^{239} \mathrm{Pu}\left(\mathrm{n}_{\mathrm{th}}, \mathrm{f}\right) \\
\text { MTA EK Budapest, Hungary }\end{array}$ & ${ }^{239} \mathrm{Pu}$ \\
\hline $1 / 4$ & $\begin{array}{c}\text { Understanding the neutron } \\
\text { spectrum in direct neutron induced } \\
\text { fission cross section measurements } \\
\text { on actinides } \\
\text { CEA Arpajon, France }\end{array}$ & ${ }^{237} \mathrm{~Np}$ \\
\hline $2 / 1$ & $\begin{array}{l}\text { Measurement of the }{ }^{240} \mathrm{Pu}(\mathrm{n}, \mathrm{f}) \\
\text { reaction cross section at the CERN } \\
\mathrm{n}_{-} \text {TOF facility EAR-2 } \\
\text { CERN, Switzerland }\end{array}$ & $\begin{array}{l}{ }^{237} \mathrm{~Np} \\
{ }^{235} \mathrm{U} \\
{ }^{238} \mathrm{U}\end{array}$ \\
\hline $2 / 3$ & $\begin{array}{c}\text { Measurement of prompt fission } \\
\gamma \text {-ray spectra characteristics from } \\
{ }^{239} \mathrm{Pu}(\mathrm{n}, \mathrm{f}) \\
\text { IPN Orsay, France }\end{array}$ & ${ }^{239} \mathrm{Pu}$ \\
\hline
\end{tabular}

Table 2. Mass fractions.

\begin{tabular}{|c|l|}
\hline & Mass fraction $(\cdot 100)(\mathrm{g} / \mathrm{g})$ \\
\hline \multirow{6}{*}{${ }^{239} \mathrm{Pu}^{*}$} & $m\left({ }^{238} \mathrm{Pu}\right) / m(\mathrm{Pu}) 0.0015(6)$ \\
& $m\left({ }^{239} \mathrm{Pu}\right) / m(\mathrm{Pu}) 99.973(4)$ \\
& $m\left({ }^{240} \mathrm{Pu}\right) / m(\mathrm{Pu}) 0.024(3)$ \\
& $m\left({ }^{241} \mathrm{Pu}\right) / m(\mathrm{Pu}) 0.0012(11)$ \\
& $m\left({ }^{242} \mathrm{Pu}\right) / m(\mathrm{Pu}) 0.00056(8)$ \\
& $m\left({ }^{244} \mathrm{Pu}\right) / m(\mathrm{Pu}) 0.000105(4)$ \\
\hline${ }^{237} \mathrm{~Np}$ & $m\left({ }^{237} \mathrm{~Np}\right) / m(\mathrm{~Np}) 100$ \\
\hline & $m\left({ }^{234} \mathrm{U}\right) / m(\mathrm{U}) 0.035973(75)$ \\
& $m\left({ }^{235} \mathrm{U}\right) / m(\mathrm{U}) 99.9336(14)$ \\
& $m\left({ }^{236} \mathrm{U}\right) / m(\mathrm{U}) 0.009629(53)$ \\
& $m\left({ }^{238} \mathrm{U}\right) / m(\mathrm{U}) 0.02073(14)$ \\
\hline \multirow{3}{*}{${ }^{235} \mathrm{U}^{*}$} & $m\left({ }^{234} \mathrm{U}\right) / m(\mathrm{U}) 0.000000592(18)$ \\
& $m\left({ }^{235} \mathrm{U}\right) / m(\mathrm{U}) 0.0007668(14)$ \\
& $m\left({ }^{236} \mathrm{U}\right) / m(\mathrm{U}) 0.000009266(42)$ \\
& $m\left({ }^{238} \mathrm{U}\right) / m(\mathrm{U}) 99.9992233(15)$ \\
\hline
\end{tabular}

presented in Table 2. The fraction for ${ }^{237} \mathrm{~Np}$ was taken from the supplier's certificate.

\subsection{Molecular plating}

The ${ }^{239} \mathrm{Pu},{ }^{237} \mathrm{~Np},{ }^{235} \mathrm{U}$ and ${ }^{238} \mathrm{U}$ deposits were prepared by the molecular plating technique which is a cathodic deposition of the actinide onto the substrate $[7,8]$. For each isotope a molecular plating cell (Fig. 1) was fabricated from polyacetal in the JRC-Geel workshop according to the required dimensions of the substrate and the deposit. The horizontally designed cell was placed in a glove box dedicated to each material. The anode is a Pt grid rotating at a speed of about 5 to 10 rounds per minute and mixing the electrolyte on top of the cathode without disturbing the deposition process. The cathode is connected to a stainless steel holder including the Al substrate which is sealed on the holder with a polytetrafluoroethylene (PTFE) compression ring. An Al ring is placed between the substrate and the PTFE ring and determines the spot diameter of the actinide deposit.

The substrates for the ${ }^{239} \mathrm{Pu}$ targets were $0.025 \mathrm{~mm}$ thick $\mathrm{Al}$ foils mounted on an $\mathrm{Al}$ ring with an outer

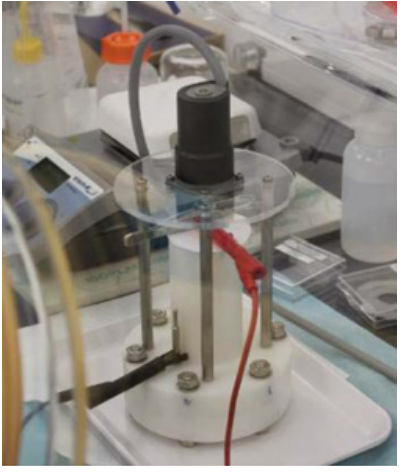

Figure 1. Molecular plating cell produced from polyacetal for the preparation of the ${ }^{238} \mathrm{U}$ deposits. The red wire is connected to the anode which is a rotating Pt grid with the motor on top of the cell and the black wire is connected to the cathode which has electrical contact with the $\mathrm{Al}$ substrate in the cell.

diameter of $40 \mathrm{~mm}$ and an inner diameter of $30 \mathrm{~mm}$. The Al backings for the ${ }^{237} \mathrm{~Np},{ }^{235} \mathrm{U}$ and ${ }^{238} \mathrm{U}$ layers had a thickness of $0.25 \mathrm{~mm}$ and a diameter of $50 \mathrm{~mm}$.

The $\mathrm{Pu}, \mathrm{Np}$ and $\mathrm{U}$ oxides were dissolved in $14 \mathrm{M}$ $\mathrm{HNO}_{3}$, evaporated to near dryness and thereafter redissolved in $0.75 \mathrm{M} \mathrm{HNO}_{3}$ at a concentration related to the required amount to be deposited on the substrate. The concentrations were verified by measuring the activity of a quantitative drop sample by alpha-particle counting at a defined solid angle. Each solution was added to isopropanol and the electrolytes were transferred into their respective cells. A voltage of $360 \mathrm{~V}$ was applied on the electrodes and the actinide layers were formed due to the movement of the charged particles in the solution when the electrical field was applied. The current at the start was about $5 \mathrm{~mA}$ for ${ }^{239} \mathrm{Pu}$ and $11 \mathrm{~mA}$ for the others and dropped after 2 hours to about $2 \mathrm{~mA}$ for ${ }^{239} \mathrm{Pu}$ and $8 \mathrm{~mA}$ for the others because of a decreased concentration of the electrolyte. After two hours the voltage was switched off and the cell was emptied. The Al substrate with deposit was heated up on a hotplate during 5 minutes at $100^{\circ} \mathrm{C}$ to evaporate the remaining isopropanol.

\subsection{Characterization}

The total alpha activity of the ${ }^{239} \mathrm{Pu},{ }^{237} \mathrm{~Np},{ }^{235} \mathrm{U}$ and ${ }^{238} \mathrm{U}$ deposits was determined by low-geometry alpha-particle counting [8,9]. The counting set-ups consisted of a silicon surface barrier detector and an electronic chain with a preamplifier, an amplifier and an analog-to-digital converter. The air pressure in the measurement chambers was below $10^{-3} \mathrm{~Pa}$.

The ${ }^{237} \mathrm{~Np},{ }^{235} \mathrm{U}$ and ${ }^{238} \mathrm{U}$ measurements were carried out with the alpha-particle counter with variable distance (LG3 counter). The ${ }^{239} \mathrm{Pu}$ targets were measured in the chamber with a fixed target-to-detector distance of $1637 \mathrm{~mm}$ (LG2 counter) and with the entrance of the chamber enclosed in a glove box due to the higher activity (Fig. 2). A set of internal baffles in the long distance tube prevented the scattering of the alpha particles in the detector.

The diameter of the deposits has not been measured directly. Instead the inner diameter of the $\mathrm{Al}$ ring mounted in the molecular plating cell on top of the substrate was measured at several positions with a calliper at room 


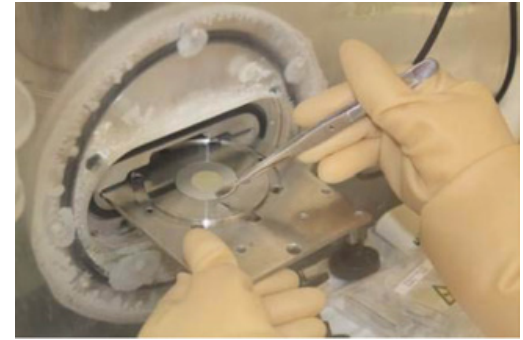

Figure 2. Mounting of an $\mathrm{Al}$ disc with a ${ }^{239} \mathrm{Pu}$ deposit in the holder of the alpha counter for low-geometry alpha-particle counting.
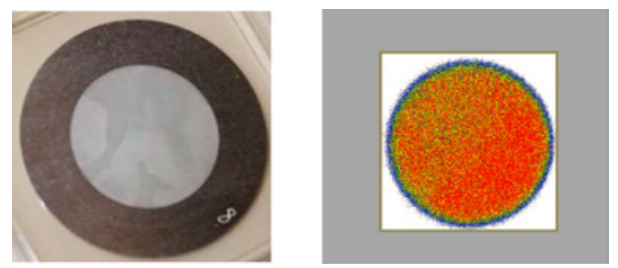

Figure 3. Left side a picture of a ${ }^{237} \mathrm{~Np}$ deposit with an areal density of $97.8 \mu \mathrm{g} \mathrm{cm}^{-2}$ on an $\mathrm{Al}$ disc and right side its autoradiograph showing the activity distribution.

temperature. The $\mathrm{Al}$ ring was touching the substrate during the deposition process and so defining the diameter of the deposit.

\section{Results}

A set of ten ${ }^{239} \mathrm{Pu}$ deposits with a diameter of $20 \mathrm{~mm}$ was prepared by molecular plating on a $0.025 \mathrm{~mm}$ thick $\mathrm{Al}$ foil mounted on an $\mathrm{Al}$ ring with an outer diameter of $40 \mathrm{~mm}$ and an inner diameter of $30 \mathrm{~mm}$. The areal density of the ${ }^{239} \mathrm{Pu}$ layers was ranging from $130 \mu \mathrm{g} \mathrm{cm}^{-2}$ to $155 \mu \mathrm{g} \mathrm{cm}^{-2}$.

Several ${ }^{237} \mathrm{~Np},{ }^{235} \mathrm{U}$ and ${ }^{238} \mathrm{U}$ layers with a diameter of $30 \mathrm{~mm}$ and an areal density between 60 and $200 \mu \mathrm{g} \mathrm{cm}^{-2}$ were prepared by molecular plating on a $0.25 \mathrm{~mm}$ thick $\mathrm{Al}$ disc with a diameter of $50 \mathrm{~mm}$. The first ${ }^{237} \mathrm{~Np}$ layers with an areal density of about $100 \mu \mathrm{g} \mathrm{cm}^{-2}$ showed spots and an irregular material distribution. So it was decided to dilute the electrolyte with a factor of two and to perform the molecular plating process twice on the same Al disc. The idea was to deposit a first layer with less material in order to have a better distribution and to create for the second layer a better adhesion. On some of the deposits with an areal density lower than $200 \mu \mathrm{g} \mathrm{cm}^{-2}$ an inhomogeneity could still be observed. To know how the actinide material was distributed over the substrate, an autoradiograph image was made. No major activity irregularities were found as shown in Fig. 3.

In general, deposits with an areal density above $130 \mu \mathrm{g} \mathrm{cm}^{-2}$ didn't show irregularities (Fig. 4).

The ${ }^{237} \mathrm{~Np},{ }^{235} \mathrm{U}$ and ${ }^{238} \mathrm{U}$ deposits were characterized for their total alpha activity by low-geometry alphaparticle counting in the LG3 counter. The background count rate was $0.007 \mathrm{~s}^{-1}$. The solid angle subtended by the $20 \mathrm{~mm}$ diameter diaphragm in front of the detector was $0.24 \%$ of $4 \pi$ sr for the ${ }^{237} \mathrm{~Np}$ and $0.42 \%$ of $4 \pi$ sr for the ${ }^{235} \mathrm{U}$ and ${ }^{238} \mathrm{U}$ measurements. A series of 10 spectra, each with a measurement time of $10000 \mathrm{~s}$ for the ${ }^{237} \mathrm{~Np}$ and $30000 \mathrm{~s}$ for the ${ }^{235} \mathrm{U}$ and ${ }^{238} \mathrm{U}$ measurements,
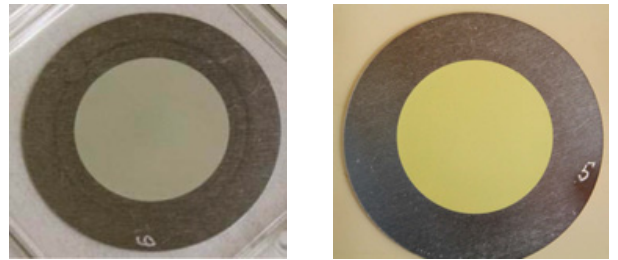

Figure 4. Left side a picture of a ${ }^{237} \mathrm{~Np}$ deposit with an areal density of $204 \mu \mathrm{g} \mathrm{cm}^{-2}$ on an $\mathrm{Al}$ disc and right side a picture of $\mathrm{a}^{238} \mathrm{U}$ deposit with an areal density of $265 \mu \mathrm{g} \mathrm{cm}^{-2}$.

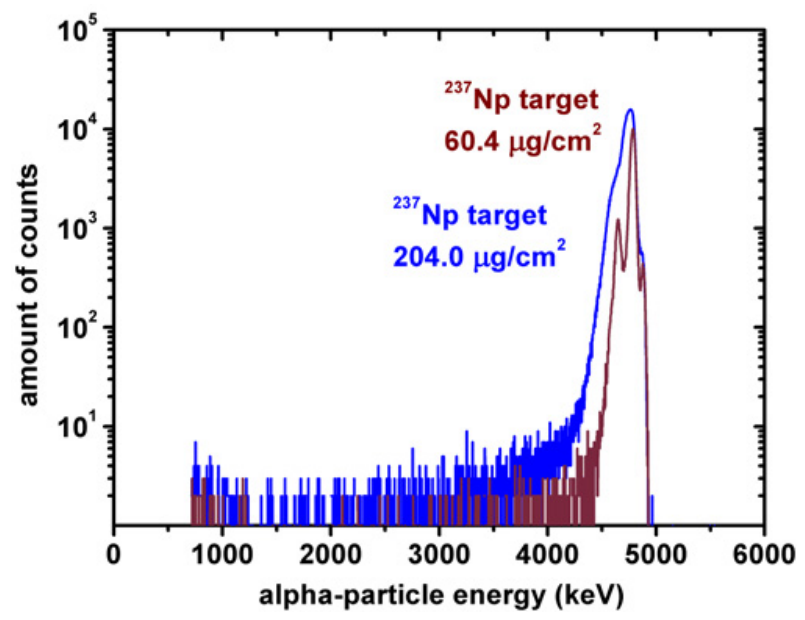

Figure 5. Alpha-particle spectra of two ${ }^{237} \mathrm{~Np}$ deposits with an areal density of $60.4 \mu \mathrm{g} \mathrm{cm}^{-2}$ and $204 \mu \mathrm{g} \mathrm{cm}^{-2}$ on an $\mathrm{Al} \mathrm{disc}$ measured in the LG3 alpha-particle counter.

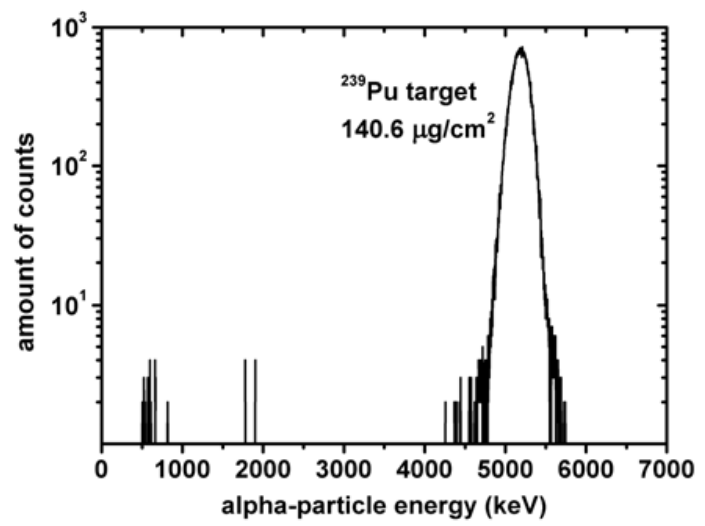

Figure 6. Alpha-particle spectrum of a ${ }^{239} \mathrm{Pu}$ deposit with an areal density of $140.6 \mu \mathrm{g} \mathrm{cm}^{-2}$ on an $\mathrm{Al}$ disc measured in the LG2 alpha-particle counter.

was acquired. Figure 5 shows two alpha-particle spectra of $30 \mathrm{~mm}$ diameter ${ }^{237} \mathrm{~Np}$ deposits with an areal density of $60.4 \mu \mathrm{g} \mathrm{cm}^{-2}$ and $204 \mu \mathrm{g} \mathrm{cm}^{-2}$. Both targets were measured for $10000 \mathrm{~s}$ at the same target-detector distance.

The ${ }^{239} \mathrm{Pu}$ targets were measured in the LG2 counter. The background count rate was $0.009 \mathrm{~s}^{-1}$. The solid angle subtended by the detector was $0.0007 \%$ of $4 \pi$ sr. A series of 10 spectra with a measurement time of $20000 \mathrm{~s}$ each was acquired. Figure 6 shows an alpha-particle spectrum of a $20 \mathrm{~mm}$ diameter ${ }^{239} \mathrm{Pu}$ deposit with an areal density of $140.6 \mu \mathrm{g} \mathrm{cm}^{-2}$.

The activity and mass of the isotope of interest was calculated from the total number of counts in the area of all alpha-particle peaks, divided by the measurement time, corrected for the background and the solid angle 
Table 3. Specifications of representative actinide targets. The combined standard uncertainties are given in parentheses and apply to the last digit(s) of the value.

\begin{tabular}{|c|c|c|c|c|c|c|c|c|}
\hline & \multicolumn{5}{|c|}{ Deposit } & \multicolumn{3}{|c|}{ Substrate } \\
\hline $\begin{array}{l}\text { CHANDA } \\
\text { PAC }\end{array}$ & Isotope & $\begin{array}{c}\emptyset \\
(\mathbf{m m})\end{array}$ & $\begin{array}{c}\text { Activity } \\
(\mathrm{Bq})\end{array}$ & $\begin{array}{c}\text { Mass } \\
(\mu \mathrm{g})\end{array}$ & $\begin{array}{l}\text { Areal density } \\
\left(\mu \mathrm{g} \mathrm{cm}^{-2}\right)\end{array}$ & Material & $\begin{array}{c}\text { Thickness } \\
\text { (mm) }\end{array}$ & $\begin{array}{c}\varnothing \\
(\mathbf{m m})\end{array}$ \\
\hline $1 / 2 ; 2 / 3$ & ${ }^{239} \mathrm{Pu}$ & $19.99(1)$ & $1013(5) \cdot 10^{3}$ & $441.2(20)$ & $140.6(7)$ & Al on ring & 0.025 & 40 \\
\hline $1 / 4$ & ${ }^{237} \mathrm{~Np}$ & $30.00(2)$ & $37535(141)$ & $1442(7)$ & $204.0(17)$ & $\mathrm{Al}$ & 0.25 & 50 \\
\hline $2 / 1$ & ${ }^{237} \mathrm{~Np}$ & $30.00(2)$ & $11114(42)$ & $427.0(21)$ & $60.4(9)$ & $\mathrm{Al}$ & 0.25 & 50 \\
\hline $2 / 1$ & ${ }^{235} \mathrm{U}$ & $29.98(2)$ & $41.37(25)$ & $518(3)$ & $73.2(11)$ & $\mathrm{Al}$ & 0.25 & 50 \\
\hline $2 / 1$ & ${ }^{238} \mathrm{U}$ & $30.00(2)$ & $23.32(28)$ & $1875(23)$ & $265(4)$ & $\mathrm{Al}$ & 0.25 & 50 \\
\hline
\end{tabular}

and the mass fraction. The areal density was calculated from the mass and diameter of the deposit which was derived from the diameter of the mask mounted on top of the substrate during the molecular plating process. The characterization results of a representative target for each isotope are presented in Table 3. The uncertainty for the diameter of the mask is the standard deviation of several measurements. For the activity, mass and areal density the combined standard uncertainty is calculated. The major components here are: the uncertainty component of the solid angle including the diameter of the active deposit, namely $0.4 \%$ and in the case of uranium the uncertainty component of the counting statistics that appeared to be also $0.4 \%$. Both uncertainty elements come from the lowgeometry alpha-particle counting procedure.

\section{Conclusion}

Deposits of ${ }^{239} \mathrm{Pu},{ }^{237} \mathrm{~Np},{ }^{235} \mathrm{U}$ and ${ }^{238} \mathrm{U}$ with an areal density ranging from $60 \mu \mathrm{g} \mathrm{cm}^{-2}$ to $205 \mu \mathrm{g} \mathrm{cm}^{-2}$ were prepared on an Al substrate by molecular plating. The mass fractions of the actinide material were determined via thermal ionisation mass spectrometry and all targets were characterised for their total alpha activity by low solid-angle alpha-particle counting. The diameter of the deposit was determined by measuring the diameter of the mask mounted on top of the substrate during the deposition process. The mass and areal density were calculated from the measured activity, the mass fractions and the diameter of the deposited ${ }^{239} \mathrm{Pu},{ }^{237} \mathrm{~Np},{ }^{235} \mathrm{U}$ and ${ }^{238} \mathrm{U}$ layer. These nuclear targets are used in experiments to solve challenges in nuclear data in the frame of the CHANDA project no. 605203 .

The authors thank the colleagues from the workshop for the production of the molecular plating cells and their technical support.

This work was partly supported by the European Commission within the Seventh Framework Programme through Fission2013-CHANDA (project No. 605203).

\section{References}

[1] http://www.chanda-nd.eu/

[2] http://www.andes-nd.eu/

[3] https://ec.europa.eu/jrc/en/eufrat

[4] http://www.erinda.org/

[5] https://indico.psi.ch/conferenceDisplay. py? $\operatorname{conf} I d=3671$

[6] https://ec.europa.eu/jrc

[7] C. Ingelbrecht, A. Moens, R. Eykens, A. Dean, Nucl. Instr. Meth. A 397, 34 (1997)

[8] G. Sibbens, A. Moens, R. Eykens, D. Vanleeuw, F. Kehoe, H. Kühn, R. Jakopic, S. Richter, A. Plompen, Y. Aregbe, J. Radioanal. Nucl. Chem. 299, 1093 (2014)

[9] J. Heyse, M. Anastasiou, R. Eykens, A. Moens, A. Plompen, P. Schillebeeckx, G. Sibbens, D. Vanleeuw, R. Wynants, J. Radioanal. Nucl. Chem. 299, 1055 (2014) 